\title{
FOURTH WORLD LITERATURE WITH SPECIAL REFERENCE TO MUSLIM MINORITY TREND IN TELUGU LITERATURE
}

\author{
Dr. Bolla Mallikharjuna Rao \\ M.A, M.Phil, PGDELT, Ph.D \\ Lecturer in English \\ PVKN Government College \\ Chittoor - AP \\ Email: drmallikharjun@gmail.com
}

\begin{abstract}
Fourth World-Anew term has developed since the 1970s. The term originated with are mark by Mbuto Milando, the first secretary of the Tanzanian High Commission and came into wide use in 1974 with the publication of Shuswap Chief George Manuel's: The Fourth World: An Indian Reality. Since then the term Fourth World is synonymous with stateless, poor, and marginal nations. Unlike the First, Second and Third World, the Fourth World does not have any political ties and is often based on a hunter-gatherer lifestyle. This area includes tribal and nomadic communities. The literature with undercurrents of caste, creed, conflict, exploitation and brutality, has encompassed the experiences of various indigenous communities like Native, Aboriginal, Maori, Dalit and Tribal groups. Arjun Dangle has said that 'Dalit' means masses exploited and oppressed economically, socially, culturally in the name of religion and other factors". Muslim Minority literature has a special entity in Telugu Literature. Though it is a part of Dalit Bhahujan Literature, at the beginning later it was developed as a separate trend. The Recent publication of an anthology of Muslim poets jolted the literary community into recognizing Muslims as a part of Telugu life. Karimulla with his long poem (Dheerga Kavitha) SAIBU expressed the feelings of an ordinary Muslims in a subtle and heartfelt manner. It is the first long poem written by a Muslim poet in Telugu literature. Thus, we can say with proud it was a great honor to the Telugu Literature that Muslimvadam started first in Indian literatures. The trend of Muslim Minorityvadam in Telugu Literature is a unique in itself.
\end{abstract}

Keywords: Mbuto Milando- fourth world- marginal nations- Dalitism -Muslim vadam in AP.

Fourth World- Anew term has developed since the 1970s. The Fourth World- The term originated with aremark by Mbuto Milando, first secretary of the Tanzanian High Commission, in conversation with GeorgeManuel, Chief of the National Indian Brotherhood of Canada. Milando stated that "When Native peoples come into their own, on the basis of their own cultures and traditions that will be the Fourth World. The term Fourth World first came into wide use in 1974 with the publication of Shuswap Chief George Manuel's: The Fourth World: An Indian Reality. Manuel thought of the Fourth World as the "indigenous peoples descended from a country's aboriginal population and who today are completely or partly deprived 
ELK

Asia Pacific Journals

of the right to their own territories and its riches. Since publication of Manuel's The Fourth World: An Indian Reality (1974), the term Fourth World is synonymous with stateless, poor, and marginal nations.

These are the most underdeveloped regions in the world. The Fourth World is used to describe the most poverty stricken, and economically troubled parts of countries in the Third World. Unlike the First, Second and Third World, the Fourth World does not have any political ties and is often based on a hunter-gatherer lifestyle. This area includes tribal and nomadic communities. They may be fully functional and self surviving units, but based on their economical performance as a whole they are placed under the Fourth World status.

Fourth World nations can consist of those excluded from society. For example, the Aboriginal tribes in South America or Australia. These tribes are entirely self sufficient, but they do not participate in the global economy. From a global standpoint, these tribes are considered to be Fourth World nations, but they are able to function free from any assistance from others. Fourth World nations do not contribute or consume anything on the global scale, and are unaffected by any global events.
ELK Asia Pacific Journals - Special Issue ISBN: 978-81-930411-1-6

Fourth World is usually used to refer to populations whose size and shape does not map onto citizenship in a specific nation-state. It can denote nations without a sovereign state, emphasizing the nonrecognition and exclusion of ethnically- and religiously-defined peoples from the politico-economic world system, e.g. the Romani people worldwide, the Basque, Sami, Pre-First World War Ashkenazi Jews in the Pale of Settlement, the Assyrians, and the Kurds in the Middle East, Pashtun throughout Afghanistan and Pakistan, the indigenous peoples of the Americas and First Nations groups throughout North, Central and South America, and indigenous Africans and Asians.

\section{Spanish sociologist Manuel}

Castells of the University of Southern California Annenberg School for Communication has made extensive use of the term fourth world'.

Fourth world literature refers to the written work of a native people living in a land that has been taken over by non-natives. Examples are the Native Americans in North America, the Maori in New Zealand, and the Aboriginals in Australia. The fourth world 
ELK

Asia Pacific Journals

literature was emerging as a diverse and universal field of study characterized by blooming of native consciousness.

The literature with undercurrents of caste, creed, conflict, exploitation and brutality, has encompassed the experiences of various indigenous communities like Native, Aboriginal, Maori, Dalit and Tribal groups. Arjun Dangle has said that 'Dalit' means masses exploited and oppressed economically, socially, culturally in the name of religion and other factors". If this definition of "Dalit" is accepted, Muslims can also be included under the category of Dalits.

Now a question arises Can minority writings in India can be considered as fourth world literature? Yes, minority literature can also be considered as fourth world literature because any literature which represents the voice of any oppressed or underprivileged victim or class of a state is called fourth world literature.

In Andhra Pradesh, next to Telugu speaking people, the largest segment of population belongs to minority Muslims. The rights of Muslims were well protected in the secular state of Andhra Pradesh. But
ELK Asia Pacific Journals - Special Issue

ISBN: 978-81-930411-1-6

the poverty, illiteracy, the poor living conditions and less job opportunities are making the majority Muslim life miserable. The massacre of Muradabad (1980), Beharsharif (1981), Meerut (1989), Bhagalpore (1989), are some of the provoking incidents in recent history that have paved way to rise of 'identity crisis' of minorities. The Babri Masjid incident (6th December, 1992) the Gujarat Carnage (2002) shook the feelings of the entire Muslim community in the country, who were made to start doubting about the very safety and security of their rights. The new phase in Telugu poetry is marked by the evolution of Muslim minority poetry. Initially backward class Muslim converts identified themselves with the Dalits. . Khaja, muslim poet, states that most of the Muslims in India are Dalits who got converted into Muslims on account of the fear of brahminism: They started reflecting on their own specific social concerns. They have now established an identity of their own.

Hurt feelings and an emotional outburst accompanied by hurling abuses at the supposed adversaries marked earlier phase of Muslim or minority poetry. 
ELK

Asia Pacific Journals

Subsequently, there emerged a path of their own, an expression reflecting their concerns and a desire for recognition as human beings first and foremost and an uninhibited desire to be accepted as fellow citizens. Muslim Minority literature has a special entity in Telugu Literature. Though it is a part of Dalit Bhahujan Literature, at the beginning later it was developed as a special separate trend. It is to be remembered after the demolition of Babri Masjid, on 6th December1992. Muslim poets showed much hatred over people who doubt Muslims Patriotism. They revolted against the state of living with fear in their own land. The carnage of Gujarat in 2002 gave raise to their extreme passions in literature. They revolted against the trend of subjugation and discrimination applied against them. At the same time they showed much resentment against religious leaders and clergy who are dictating their lives in the name of Islam. They advocate reforms and are against the abuse of Status of women in Islam. The Muslim writers, One side they are opposing the Hindutva forces and at the same time they are also fighting for reforms in their religion.
ELK Asia Pacific Journals - Special Issue

ISBN: 978-81-930411-1-6

The Muslim writers' powerfully depicted the socio, economic, educational and political backwardness of a community apartment from crisis and insecurity of religious minority. The literature wages a struggle for dignity of a community and social justice. Telugu literature, particularly modern Telugu literature, is known for the works that condemn social evils and speak of realizing justice to the politically marginalized and socially, economically suppressed sections of the society. Muslim minority writers made a mark to enrich Telugu Literature. Khaja opines that the issue of 'Muslim as a minority' has strongly proved its existence in Telugu poetry both in content and form.Yakoob, Khaza Mohiuddin, Afsar, Mahejabeen, Khasim and others are among the prominent Muslim minority poets. Khader, Skybaba, Khaja, Khadeer Babu, Salim, Sharif, Afsar, Mahjabeen, Shajahana, Karimulla are found voicing the identity problems of Muslims in Andhra Pradesh in particular and India in general.

For decades, Telugu Writers came from the Hindus, with significant exceptions such as Umar Ali Sha (1885-1945) who wrote during the thirties, and more recent and 
ELK

Asia Pacific Journals

well-known poets such as Ismail,Smile, Afsar, and Khadar Mohiuddien. An explosion of a sizable group of Telugu writers from the Muslim community has indeed expanded the literary space beyond the limits the majority communities imagined. Though a majority of Muslims in Andhra Pradesh are Urdu-speaking, more and more Muslims learning Telugu and penning verse in the language, Muslim poets have made a mark of their own with their unique flavor of national integration and communal harmony interspersed with the demand for the rights of the principal minority community.

Muslim poets say that they believe in the basic concept of universal brotherhood which is the basic tenet of the Islam and convert them in to Islam though they are Dalits. They condemn the trend of branding ordinary Muslims as terrorists, and scare the whole community in the guise of terrorism. Muslims were made scapegoats where ever bombs were exploded in India

There are over 80 Telugu Muslim poets and scores of poetry books have been published. It is the beginning of an era; the era that heralds a new phase Telugu literature. It has given Muslims, an opportunity to
ELK Asia Pacific Journals - Special Issue

ISBN: 978-81-930411-1-6

express their views and problems and share them with the rest of society,"

The Muslim Telugu Poets are Syed Naseer Ahmed,.Devi Priya (Khaja Hussain),Afsar, Smile, Kaumudi, MK Sugam Babu (Mahboob Khan), Umar Ali Shah, Dilawar, Ismail, Yakoob, Khadar Mohiuddin, Ghulam Ghouse, SA Rawoob, SM Mallick, Qadeer Babu and Khadar Khan. The torch is now being carried forward by the likes of Khwaja, Sky Baba (Shaik Yusuf Baba), Wahed, Soujanya, (Muhammad Nafijuddin) Iqbal Chand, Khaseem, Karimulla, Khaza Mohiuddin,Mahejabeen,Salim,Sharif,Shajah ana,Dani,ShaikHussain,Vali Hussain, Sikandar, Haneef, Rahamatulla, and Dada Hayat . These Muslim poets have carved out a niche for themselves with their unique style and rendition of the Telugu poetry.The Recent publication of an anthology of Muslim poets jolted the literary community into recognizing Muslims as a part of Telugu life. Jaljala(1998) published by the Muslim Poets, claims to be the first such anthology in Telugu. Jala Jala, the poetry collection and Watan, a collection of short stories is landmark in Muslim literature in Telugu. It has followed by considerable literary and political writing. 
ELK

Asia Pacific Journals

Anthologies of Muslim Minority

Poets such as Jehad, Mukhuta, Jayam, Blackvoice, Fatwa, Aaza, Mulki,Arovarnam, Dhu, Valasa, and Saibu are published. Many poets in this anthology are new, and come from varied backgrounds. Stories, Novels, depicting the lifestyle of Muslims came into light. Khadar Mohiuddin brought literary attention to the Muslim identity question. His "Birthmark" debunks the complacent liberal sensibilities of modern poetic language by exposing its ideological bankruptcy and its pseudo-liberal dullness. The long poem, which starts as a personal biography, unfolds into a story of a community meandering through the crooked lanes of history. It ends by making an indelible impression of communal hypocrisy on the consciousness of the readers. Khadar Mohiddin Published his Puttumacha(Birthmark) before the arrival of Muslim Minority vadam.

Rahmutulla 'Bha' and Khadeebabu's stories provide the life and struggles of Muslims in everyday life Syed Saleem a novelist, storyteller, poet, humanist and idealist wrote short fiction also. His story collections and novels Provide voice to every anguish, agony and glimpses of the intense pain of
ELK Asia Pacific Journals - Special Issue

ISBN: 978-81-930411-1-6

existence in a world hurrying to embrace an irreversible decline of all that is essential for survival of life on the planet. One of his novels Kaalutunna Poola Thota (The Burning Garden) stands out as the coveted Central Sahitya Academy award winner. It also won an award from the National Human Rights Commission. His Vendi Megham (Silver Cloud) is a novel about how a Muslim woman regards the social and family arrangements around her as creating existentialist problems in her search for fulfillment. Salems' claim that it is the first novel to depict Muslim lives in Telugu Literature may go uncontested.

Karimulla with his long poem (Dheerga kavitha) SAIBU expressed the feelings of an ordinary Muslims in a subtle and heartfelt manner. It is the first long poem written by a Muslim poet in Telugu literature. Skybaaba's "Adure" is a collection of short stories depicts the day to day life of the Muslims in urban and rural areas. These stories voice the fragrance and misery of the life of the Muslim families. "Adure" is the first collection of short stories written by a Muslim storyteller in Telugu on the social conditions of Muslim families. Khaja is the pioneer of Muslim poetry in telugu 
ELK

Asia Pacific Journals

literature. He published his anthology of poetry Fatwah in 1998 and published Muslimvada Tatvikata (A literary Philosophy of Muslimism) in 2005. Afsar is known for his deeply nuanced language, subtle and subversive. He works his way in a quiet voice and ends just as quietly, as if he has said nothing worthwhile, but he is devastating in his undertones.

There is Telugu Muslim poetess too, of the likes of Mahjabeen and Shahjahana. The State Government of Andhra Pradesh has honored Mahjabeen with the Ugadi Puraskar (award) for Telugu literature. Shahjahana is an unusual poetess with remarkable talent. Very new to the literary field, she makes a name with a small number of poems and promises to grow to be a major poet. Sajahana, reflects in her writings the agony of Muslim women. Muslim women face different oppression. Their life is absolutely conditioned by their religion. Muslim women are facing trouble with the unwanted rules and regulations socially .The poetess goes on depicting the misery suffered by Muslim women in her poems and she wrote against Veil system prevalent in Muslims in her Poem 'Nakhab' in a powerful way. She has concentrated on the feelings of Muslim
ELK Asia Pacific Journals - Special Issue

ISBN: 978-81-930411-1-6

women when they wear 'Burkha' and She airs a feeling of protest at this boundless agony: She tries to fill the hearts of Muslim women with the courage to break the shackles of misery.

Two poets, Afsar and Shajahana turn inward to explore the problem of minority existence. The dialogue in both these poets is internal but the reader is given the opportunity of overhearing, and-as in all good poetry- what you overhear is what is intended

Thus, we can say with proud it was a great honor to the Telugu Literature that Muslimvadam started first in Indian literatures. The trend of Muslim Minorityvadam in Telugu Literature is a unique in itself.

\section{REFERENCES}

[1] Fourth World - Wikipedia, the free encyclopedia

[2] The Meaning of "Nation" and "State" in the Fourth World by Dr. Richard Griggs University of Cape Town

[3] Fourth World: Definition from Answers.com 
ELK

Asia Pacific Journals
ELK Asia Pacific Journals - Special Issue ISBN: 978-81-930411-1-6

[4] Telugu Sahityam-Ninna-NeduRepu by G. Sambasiva Rao

[5] Muslim Minorityvadam - The Hindu

[6] Telugu Muslims Literature in search of a friend-Kesav

[7] Alpana Gupta -Telugu Dalit Poetry as an Expression of Socio-Politico Historical Change 